\title{
内視鏡下摘出術が有効であった腰椎椎間板囊腫の一例
}

\author{
野 村 裕* 土 井 俊 郎* 播广谷 勝 三* \\ 松 本 嘉 寛* 岩 本 幸 英*
}

\section{A Case Report of Lumbar Discal Cyst Treated by Microendoscopic Tumorectomy}

\author{
Hiroshi Nomura*, Toshio Doi*, Katsumi Harimaya*, \\ Yoshihiro Matsumoto*, and Yukihide Iwamoto*
}

\begin{abstract}
我々は腰椎椎間板囊腫の症例に対し，内視鏡下囊腫摘出術を施行したので報告する。症例は 28 歳，男 性である.4 ケ月前より, 誘因なく, 腰痛と左下肢痛が出現した。症状は腰椎椎間板へルニアに類似して いた. MRIにて，L4/5 椎間板に連続する T1W I にて低信号域，T2W I にて高信号域，ガドリニウム造 影にて周囲がリング状に造影される腫瘍性病変を認めた. この症例に対し，内視鏡下摘出術を施行した. 左 L5 神経根は囊腫によって圧排されていた。囊腫は L4/5 椎間板と連続しており，これを摘出した。囊 腫壁は線維性組織によって構成されていた。術後，下肢痛は寛解した。腰椎椎間板囊腫は 2001 年に報告 されて以来，少数の症例が報告されているのみの稀な疾患である。この症例に対し，内視鏡下摘出術は有 効であつた.
\end{abstract}

Lumbar discal cyst is rare. We report a case with lumbar discal cyst who underwent resection using a microendoscopic discectomy (MED) system. A patient was 28-year-old man suffered from severe left lower-extremity pain and low back pain for 4 months, whose symptoms resembled those of lumbar disc herniation. Magnetic resonance images showed a cystic lesion connecting to intervertebral disc at the level of L4/5 with low signal intensity on T1-weighted and high on T2-weighted images, and the peripheral rim of the cyst was enhanced by intravenous injection of gadolinium on fat-suppressed T1-weighted images. As these images suggested a lumbar discal cyst, we performed tumorectomy using the MED system. In the operation, the cystic mass connecting to intervertebral disc at the level of L4/5 that strongly compressed the left L5 spinal nerve root was observed in detail by MED system. It was extirpated safely. Histopathological examination revealed that the cyst wall was composed of dense fibrous tissue without specific lining cells. The symptoms disappeared immediately after surgery with no post-operative low back pain. We suggest that the MED system is useful to treat lumbar discal cysts.

Key words : lumbar discal cyst（腰椎椎間板囊腫）， microendoscopic tumorectomy（内視鏡下腫瘍 摘出術), lumbar spine (腰椎)

\section{は じめ に}

腰椎椎間板囊腫は少数の症例が報告されているのみ

の稀な疾患である. 我々は腰椎椎間板囊腫の症例に対

し, 内視鏡下摘出術を施行したので報告する.

症例

症例 : 28 歳, 男性.
初診の 1 年前より誘因なく腰痛が出現し，4 ケ月前 より徐々に左下肢痛が出現した. 近医にて腰椎腫瘍性 病変を疑われ，紹介受診となった．初診時現症では， 左下肢伸展挙上テストが陽性で, $40^{\circ}$ 挙上にて左第 5 腰髄（L5）神経根領域に高度の疼痛を生じた。明ら かな左下肢の筋力低下や知覚異常を認めなかつた. 日 本整形外科学会臨床評価点数（JOA score）は $9 / 29$ であった. MRI では，L5 腰椎上縁後方で L4/5 椎間

\footnotetext{
* 九州大学医学部整形外科 Department of Orthopedic Surgery, Kyushu University, Fukuoka, Japan
} 

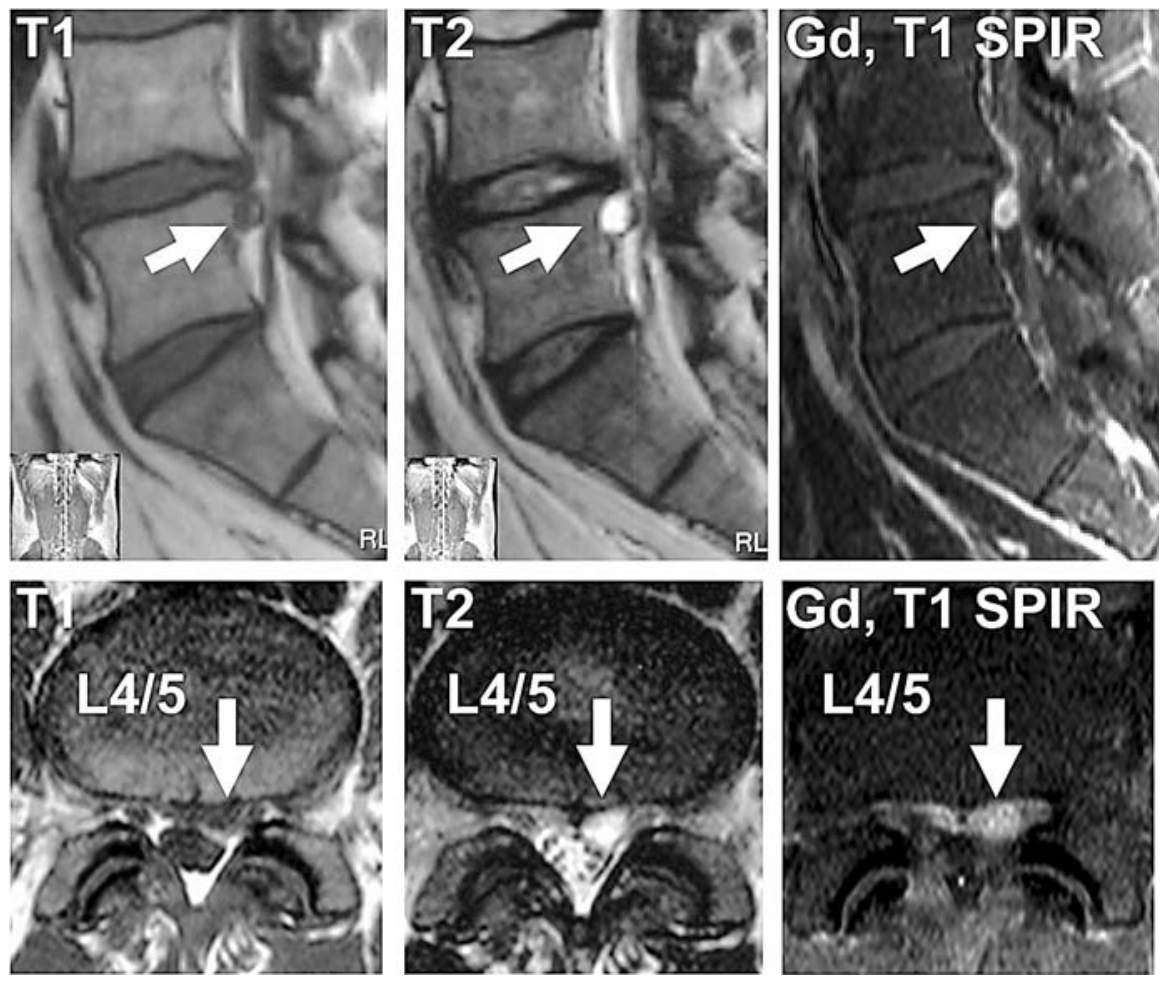

図 1 術前 MRI. L4/5 椎間板に連続する T1W I にて低信号域, T2W I にて高信号域, ガドリニウム造影 T1W I, SPIR 像にて周囲がリング状に造影される腫瘍性病変 を認める。

板に連続する T1W I にて低信号域，T2W I にて高信 号域，ガドリニウム造影にて周囲がリング状に造影さ れる腫瘍性病変を認めた（図 1 )。春髄造影では左 L5 神経根の陰影欠損を認めた。造影後 CT 検査では, 腫 瘍性病変と硬膜管の交通を認めなかった，椎間板造影 は行わなかった。この症例に対し，腰椎椎間板囊腫を 疑い，内視鏡下摘出術を施行した。術中所見にて，左 L5 神経根は発赤を認め, 腹側の囊腫のために背側に 圧排され可動性を欠いていた。囊腫は L5 神経根の腋 窩部に存在しており，L4/5 椎間板と連続していた （図 2)。色調は赤褐色から黄色で，内部に黄色透明な 内容液の貯留を認めた。内視鏡下に囊腫を摘出した. 病理組織検査にて, 囊腫壁は線維性組織によって構成 されており，囊腫内壁に lining cell は認めなかった (図 3)。術後, 下肢痛は寛解し, 術後腰痛も認めなかつ た. 術後 2 週の JOA score は29/29 であった.

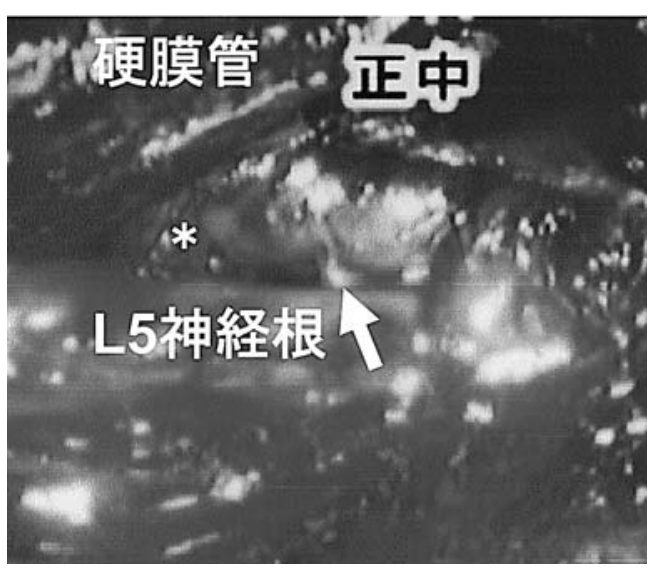

図 2 術中写真. 左 L5 神経根は L4/5 椎間板レベル に存在する囊腫（矢印）により圧排されていた. 囊腫は L $4 / 5$ 椎間板（*) と連続している。 写 真の右側が頭側。 

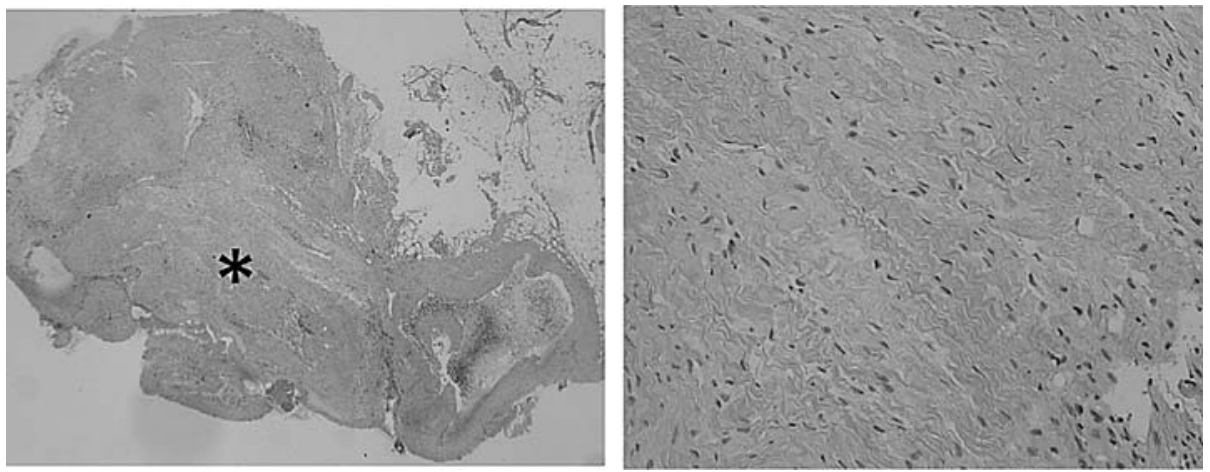

図 3 病理組織検査. 囊腫壁は線維性組織によって構成されており, 囊腫内壁に lining cell は認めない. 右図は左図（*) の拡大.

考察

腰椎椎間板囊腫は腰椎脊柱管内に発生する硬膜外囊 腫状病変の一つとして，2001 年に千葉らによって報 告された ${ }^{1} .30$ 代の男性に好発し, 臨床症状は腰椎椎 間板ヘルニアに類似した腰痛と下肢症状である"). MRI では, 腰椎椎間板囊腫は T1W I で低信号域, T2W I で高信号域，ガドリニウム造影で周囲がリン グ状に描出される特徵をもつ $)^{5}$. 本症例では行ってい ないが，椎間板造影では造影剤が囊胞内に流入する。 千葉らは造影された囊腫の外観より, 腰椎椎間板囊腫 を type I からVに分類している ${ }^{1)}$. 画像上鑑別すべ き囊胞性疾患として perineural cyst, extradural arachnoid cyst, synovial cystなぞが挙げられるが, それぞれの画像上の特徵よりある程度鑑別可能であ る45)，当症例では，MRIが診断に有用であった．

腰椎椎間板囊腫発生の仮説として，何らかの原因で 椎間板の線維輪が破綻し, 出血又は漏出した漿液が正 中外側の ventral epidural space に流入後, 生体反 応による膜形成が生じるのではないかと推測されてい る ${ }^{477}$ ．当症例では，内視鏡の使用により，術中に腰椎 椎間板囊腫のマクロ病変を詳細に観察できた。囊腫は 椎間板と明らかに連続しており, 椎間関節や硬膜管と は不連続であった。内容液はその性状や色調より漿液 性であり，先の仮説に矛盾しない所見であった，病理 組織所見でも囊腫内壁に lining cell を認めておらず, 囊腫自体が内容液を産生した証拠はなかった.

腰椎椎間板囊腫の手術成績は一般に良好で, 術直後 より下肢症状が消失したとの報告が多( ${ }^{1224(4)}$ ，近年の
内視鏡下手術の発達は目覚しく, 春柱管内囊腫性病変 に対する内視鏡下摘出術は有用であるとの報告があ る3.．当症例では内視鏡を使用することによって確実 な視野を確保し，囊腫を安全に摘出することができた. 術後腰痛も伴わず，臨床結果は極めて良好であった．

$$
\text { ま と め }
$$

腰椎椎間板囊腫に対する内視鏡下摘出術は，術中に 詳細なマクロ所見の観察が可能で，且つ症状の寛解と 術後腰痛の発生が抑えられ，有効な方法であった。

\section{参 考 文 献}

1) Chiba, K., et al.: Intraspinal cyst communicating with the intervertebral disc in the lumbar spine: discal cyst. Spine, 26 (19) : 2112-2118, 2001.

2) Coscia, M. F., Broshears, J. R.: Lumbar spine intracanalicular discal cysts: two case reports. J. Spinal Disord. Tech., 15(5) : 431-435, 2002.

3) Ishii, K., et al.: Endoscopic resection of cystic lesions in the lumbar spinal canal. A case report of two cases. Minim. Invas. Neurosurg., $48: 240-243$, 2005.

4）鹿毛淳史ら：腰椎 discal cyst の 1 例. 脳神経外科, 36(2) : 159-163, 2008.

5) Lee, H. K., et al.: Discal cyst of the lumbar spine: MR imaging feature. Clinical Imaging, $30: 326-330$, 2006.

6) Nabeta, M., et al.: Discal cysts of the lumbar spine. J. Neurosurg. Spine, 6:85-89, 2007.

7） 戸山芳昭ら：椎間板と交通する春柱菅内囊腫（椎間板 囊腫）－発生機序の考察と新しい疾患名の提唱一。臨整 外, $32:$ 393-401, 1997. 